www.nature.com/clinicalpractice/rheum

\title{
Potential new drug targets for osteoporosis
}

\section{Chad Deal}

Nature Clinical Practice Rheumatology (2009) 5: 20-27 [DOI:10.1038/ncprheum0977]

doi:10.1038/ncprheum1027
In the January 2009 issue, in the Review by Deal, the randomized controlled trial evaluating four doses of odanacatib was described incorrectly on page 22. In this trial odanacatib was given weekly, not daily.
There was also an error in the corresponding author's email address. The correct address is dealc@ccf.org. 